\title{
Effect of the bovine TG5 gene polymorphism on milk- and meat-producing ability
}

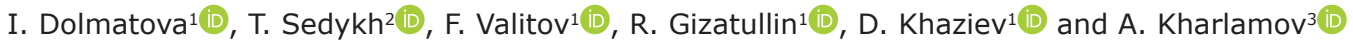 \\ 1. Federal State Budgetary Educational Institution of Higher Education, Bashkir State Agrarian University, Ufa, Russia; \\ 2. Ufa Branch of the Russian Academy of Sciences, Bashkir Scientific Research Institute of Agriculture, Ufa, Russia; \\ 3. Federal State Budgetary Scientific Institution, Federal Scientific Center for Biological Systems and Agrotechnologies of \\ the Russian Academy of Sciences, Orenburg, Russia. \\ Corresponding author: I. Dolmatova, e-mail: dolmatovairi@rambler.ru \\ Co-authors: TS: nio_bsau@mail.ru, FV: valitovfa@rambler.ru, RG: gizatullinri@rambler.ru, DK: khazievda@rambler.ru, \\ AK: kharlamovana@rambler.ru \\ Received: 04-05-2020, Accepted: 17-08-2020, Published online: 02-10-2020
}

doi: www.doi.org/10.14202/vetworld.2020.2046-2052 How to cite this article: Dolmatova I, Sedykh T, Valitov F, Gizatullin R, Khaziev D, Kharlamov A (2020) Effect of the bovine TG5 gene polymorphism on milk- and meat-producing ability, Veterinary World, 13(10): 2046-2052.

\begin{abstract}
Aim: This study aimed to determine the effect of thyroglobulin (TG5) gene polymorphism on milk and meat productivity in the various cattle breeds currently bred in the Republic of Bashkortostan.
\end{abstract}

Materials and Methods: The test was performed on dairy cattle of Black-and-White, Bestuzhev, and Simmental breeds, and meat cattle of Hereford and limousine breeds. The purpose of the test was to search for associations between the polymorphic alleles of the thyroglobulin $(T G 5)$ gene and economically useful traits.

Results: All studied breeds showed a frequency predominance of the $T G 5^{C}$ allele (from 0.56 to 0.71 ). A clear trend of an effect of the genotypes of the $T G 5$ gene on milk-productivity indicators was revealed; cows with the $T G 5^{T T}$ genotype have the highest milk yield and fat content in milk. The milk of cows of Bestuzhev and Simmental breeds that possessed this genotype was also characterized by higher protein content.

Conclusion: We identified an effect of the polymorphism of the TG5 gene in the Hereford and limousine breeds on fat metabolism intensity indicators, such as fat output and fat content, in the longissimus muscle and in the general sample of ground beef.

Keywords: alleles, dairy and meat productivity, genetic polymorphism, Hereford breed, limousine breed, thyroglobulin gene.

\section{Introduction}

At present, domestic and foreign scientists are actively studying the genetic determination of the dairy and meat production characters of cattle using DNA markers. This will allow supplementing traditional breeding methods with the method of selecting animals based on desirable genetic markers. Thus, it will become possible to significantly accelerate the selection process by improving the genetic potential of cattle breeds [1,2]. It will be possible to maintain the desired economic and useful characteristics during cattle breeding by determining the quantity and quality of the products [2-4].

Polymorphic genes encoding hormones such as somatotropin, prolactin, and thyroglobulin are primarily considered candidate genes that determine the level of dairy and meat productivity of cows. The pituitary protein hormones prolactin and somatotropin are

Copyright: Dolmatova, et al. Open Access. This article is distributed under the terms of the Creative Commons Attribution 4.0 International License (http://creativecommons.org/licenses/ by/4.0/), which permits unrestricted use, distribution, and reproduction in any medium, provided you give appropriate credit to the original author(s) and the source, provide a link to the Creative Commons license, and indicate if changes were made. The Creative Commons Public Domain Dedication waiver (http:// creativecommons.org/publicdomain/zero/1.0/) applies to the data made available in this article, unless otherwise stated. directly involved in the initiation and maintenance of lactation in mammals. The glycoprotein thyroglobulin is a precursor of the thyroid iodothyronine hormones, which modulate many physiological and biochemical processes in almost all tissues of the body by regulating gene expression. Thyroid hormones also affect the differentiation of adipocytes into adipose tissue. Therefore, the thyroglobulin gene is considered a candidate gene that affects the ability to accumulate fat in tissues, including milk [5].

The thyroglobulin $5^{\prime}$ leader sequence (TG5) gene is one of the longest mammalian genes. In cattle, it is located in the centromere region of the $14^{\text {th }}$ chromosome and consists of 37 exons [6-9]. The TG5 gene has two allelic variants, $T G 5^{T}$ and $T G 5^{C}$, and three genotypes, $T G 5^{C C}, T G 5^{C T}$, and $T G 5^{T T}$.

The analysis of the research results of domestic and foreign colleagues confirmed that the TG5 gene should be considered a functional and positional candidate gene that affects the accumulation of fat in the body. In fact, a single-nucleotide polymorphism located in the $5^{\prime}$ untranslated region of this gene is used for marker-based selection aimed at increasing marbling [10]. Several studies have revealed an association between thyroglobulin gene polymorphism and fat metabolism, particularly intramuscular fat [11-15], 
as well as milk yield and quality $[11,16,17]$. Thus, cows of the Kholmogorsky breed of the Tatarstan type carrying the $T G 5^{C T}$ and $T G 5^{T T}$ genotypes surpassed their age equals carrying the $T G 5^{C C}$ genotype regarding milk yield and mass fraction of fat in milk. On average, more milk fat per lactation was obtained from the first-born cows of different breeds with the $T G 5^{C T}$ and $T G 5^{T T}$ genotypes compared with cows with the $T G 5^{C C}$ genotype.

Despite the identification of several trends in this field of research, it is evident that the introduction of marker-based selection in practical cattle breeding requires an improved analysis of the gene pool of domestic breeds. This will help increase the intensity of the improvement of the genetic potential of domestic breeds of cattle.

This study aimed to determine the effect of TG5 gene polymorphism on milk and meat productivity in the various cattle breeds currently bred in the Republic of Bashkortostan.

\section{Materials and Methods \\ Ethical approval}

Housing conditions for the animals in the experimental groups were the same. Investigational study and animal management meet the requirements of the Russian Regulations, 1987 (Order No. 755 on 12.08.1977 the USSR Ministry of Health) and «The Guide for Care and Use of Laboratory Animals (National Academy Press Washington, D.C. 1966)〉. Every possible effort was made during the research to minimize animals' distress and use fewer samples.

\section{Study period}

The subject of the research made from 2014 to 2018 was milk and meat-type cattle population of the Republic of Bashkortostan.

\section{Animals and location of the study}

First-calf cows of the Black-and-White (Limited Liability Company [LLC] Agricultural Enterprise named after the Kalinina Sterlitamakskii district; $n=379$ ), Bestuzhev (LLC Agrofirma "Idel," Nurimanovskii district; $\mathrm{n}=150$ ), and Simmental (LLC JV "Trudovik," Meleuzovskii district; $n=150$ ) breeds were used as the material for on the study of the relationship between the TG5 gene polymorphism and milk productivity.

The samples were formed using the method of balanced groups, considering the date of birth and the calving date (first lactation). Milk productivity data were obtained from the electronic database of the "Selex" enterprise information system. The analysis of milk composition was performed in the milk quality selection control laboratory of "Bashkirskoe" JSC, which specializes in breeding programs based on the use of a "Lactan 700M" device. The amount of milk fat was calculated by dividing one percent milk obtained over the considered lactation period by 100 .

The analysis of meat productivity indicators in relation to the $T G 5$ gene polymorphism was performed on animals of the Hereford (SAVA-Argo-Usen LLC, Tuymazinskii district; $n=115$ ) and limousine (SAVAAgro-Iapryk LLC, Tuymazinskii district; n=114) breeds. Hereford bulls were the offspring of animals imported from Australia in 2009. Limousine bulls were the offspring of animals bred by accumulation crossing of Simmental cattle with limousine servicing bulls of French selection. Both farms use stable and open-grazing keeping of meat cattle according to the "cow-calf" system with resource-saving elements. The farms were stud farms that specialize in particular breeds of unique meat cattle and maintain feeder animals for beef production. Bulls were raised and fed until the age of 20 months. Live-animal indicators of meat productivity (bodyweight of young animals at birth, absolute and average daily weight gain, and relative growth rate over the entire growing period) and gained bodyweight (bodyweight at the end of fattening of young animals), as well as postmortem indicators, were considered in the determination of meat quality during the experiment.

\section{Sample collection and analysis}

DNA samples were obtained from whole blood using a set of "DNA-Extran" ("Syntol" LLC). Genotyping of the TG5 gene was performed in the animals through the PCR-RFLP method using the following primers [18]:

- TG5 1:5'-GGGGATGACTACGAGTATGACTG-3' - TG52:5'-GTGAAAATCTTGTGGAGGCTGTA-3'.

The resulting amplified fragments of the TG5 gene were cleaved by the BstX2I endonuclease at $37^{\circ} \mathrm{C}$ for $12 \mathrm{~h}$. Electrophoresis of restriction products was performed in 7\% polyacrylamide gels with the addition of ethidium bromide in $0.5 \times$ TBE buffer. The Doc XR gel documentation system and the Image Lab software, 2.0 "DNA-analyzer" version, were used to analyze the gel images. The molecular mass marker used was the $100 \mathrm{bp}+1 \mathrm{~kb}$ marker provided by the Sibenzim company.

The formula determined the genotype frequency:

$$
p=n N
$$

where $p$ is the genotype frequency;

$n$ - the number of animals with a specific genotype;

$N$ - number of animals.

The frequency of individual alleles was determined using the following formulas:

$$
R S=(2 p s S+P S T) 2 N
$$

where $p C$ is the frequency of the $C$ allele.

$$
q T=(2 p t t+P S T) 2 N
$$

where $q T$ is the frequency of the $T$ allele.

The expected degree of heterozygosity was calculated $\left(\mathrm{H}_{\mathrm{e}}\right)$ using the formula: 


$$
H_{e}=1-\sum_{p_{i}}^{2}
$$

where $p_{i}$ is the $\mathrm{i}$-th allele frequency.

The observed level of heterozygosity $\left(H_{o}\right)$ was calculated using the formula:

$$
H_{o}=n N
$$

where $n$ is the number of animals that are heterozygous for this allele,

$N$ is the sampling size.

For assessing the correspondence of the actual and expected distribution of genotypes in the studied animal samples, the $\chi^{2}$ criterion was used, which was calculated using the formula:

$$
x^{2}=\sum^{k}(O-E)^{2} / E
$$

where $O$ and $E$ are the observed and theoretically expected numbers of genotypes of a particular type,

$k$ is the number of genotypic classes.

Statistical processing of the quantitative indicators of dairy and meat productivity in animals was performed using a standard method and the "Excel" software of the "Microsoft Office" package.

\section{Results and Discussion}

Figure-1 shows an electropherogram of the results of PCR-RLFP of the TG5 gene. The $T G 5^{C C}$ genotype was represented by restriction fragments of 295, 178, and $75 \mathrm{bp}$ (tracks 1 and 2); the $T G 5^{T C}$ genotype was represented by 473, 295, 178, and 75 bp fragments (tracks 3 and 4); and the $T G 5^{\mathrm{TT}}$ genotype was represented by 473 and 75 bp fragments (tracks 5, 6, and 7).

The frequency of the TG5 genotypes in the animals of the studied breeds is shown in Table-1. It

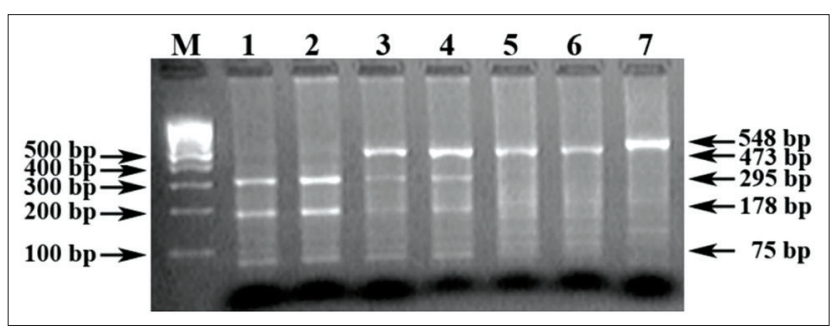

Figure-1: Electrophoregram of the result of TG5 gene identification of cattle. should be noted that, in general, the TG5 genotypes were distributed similarly among the four studied breeds, with the exception of Simmental. Specifically, the frequency of the $T G 5^{C C}$ genotype was very high, ranging from $47.32 \%$ to $65.8 \%$. The heterozygous $T G 5^{C T}$ genotype ranked second in frequency (27.9$43.0 \%$ ), and the $T G 5^{T T}$ genotype ranked third (6.3$13.4 \%$ ) in frequency. In contrast, more than half of the studied animals of the Simmental breed (62.7\%) had the $T G 5^{C T}$ genotype, whereas $23.2 \%$ carried the $T G 5^{C C}$ and $14.1 \%$ had the $T G 5^{T T}$ genotypes.

The $T G 5$ gene allele frequencies in the various breeds of cattle are shown in Figure-2. The analysis of the graphic data revealed that the frequency of the $T G 5^{C}$ allele was high in all breeds, especially in the Bestuzhev (0.80), Hereford (0.71), and Black-andWhite $(0.70)$ breeds.

The data obtained were in good agreement with the results of domestic research. Soloshenko et al. [19] found that, among the Hereford cattle bred in Siberia, $65 \%-76 \%$ of animals have the $T G 5^{C C}$ genotype, $20-35 \%$ carry the $T G 5^{T C}$ genotype, and $2 \%$ have the $T G 5^{T T}$ genotype (identified only in one herd). The study of the Hereford cattle bred in Tatarstan [20] showed that none of the animals carried the $T G 5^{T T}$ genotype. In limousine cattle, the frequency of the $T G 5^{T T}$ genotype was $22.6 \%$, whereas the $T G 5^{C T}$ genotype was present in $29 \%$ of these animals and in $11.1 \%$ of Hereford cattle. Moreover, a population-genetics analysis of beef cattle bred in Ukraine revealed that the frequency of the $T G 5^{C T}$ genotype in the Hereford breed was $0.23 \%$ [21]. According to Barendse et al. [7], the highest marbling was noted in the Japanese Wagyu breed, in which the frequency of the desired TT genotype reaches $76 \%$.

According to Tiul'kin et al. [16], 62.9\% of purebred and crossbred Holstein bulls have the $T G 5^{C C}$, $35.7 \%$ possess the $T G 5^{C T}$, and only $1.4 \%$ have the $T G 5^{T T}$ genotype. No animals with the $T G 5^{T T}$ genotype were found in a herd of Black-and-White Holstein cows.

Thus, the analysis of the frequency of the various genotypes of the TG5 gene indicates the presence of genetic potential among specialized breeds of beef cattle in relation to the taste and nutritional qualities of meat. The foreign origin of beef cattle can explain the relatively high proportion of animals with the desired

\begin{tabular}{|c|c|c|c|c|c|c|c|}
\hline \multirow[t]{3}{*}{ Breed } & \multirow[t]{3}{*}{$n$} & \multicolumn{6}{|c|}{ The frequency of the genotype } \\
\hline & & \multicolumn{2}{|c|}{ TG5 $5^{c c}$} & \multicolumn{2}{|c|}{ TG5 ${ }^{C T}$} & \multicolumn{2}{|c|}{$T G 5^{T T}$} \\
\hline & & Animals & $\%$ & Animals & $\%$ & Animals & $\%$ \\
\hline Black-and-White & 379 & 186 & 49.0 & 163 & 43.0 & 30 & 8.0 \\
\hline Bestuzhev & 150 & 99 & 65.8 & 42 & 27.9 & 9 & 6.3 \\
\hline Simmental & 150 & 35 & 23.2 & 94 & 62.7 & 21 & 14.1 \\
\hline Hereford & 115 & 60 & 52.17 & 44 & 38.26 & 11 & 9.57 \\
\hline Limousine & 112 & 53 & 47.32 & 44 & 39.28 & 15 & 13.40 \\
\hline
\end{tabular}
$T G 5^{T T}$ genotype identified here.

Table-1: Genotype frequencies for the TG5 gene. 
The actual and expected levels of heterozygosity of the TG5 gene among the studied samples are shown in Table-2. Out of the three dairy breeds, only the Black-and-White breed was in the state of genetic equilibrium for the TG5 gene. The actual number of heterozygotes in this breed corresponded to the theoretically expected number calculated according to the Hardy-Weinberg law. The most significant deviation from the actual and expected distribution of genotypes was found in the Simmental breed sample, which exhibited a relatively significant excess of $T G 5^{C T}$ heterozygotes. This caused some lack of both $T G 5^{C C}$ and $T G 5^{T T}$ homozygous genotypes. In the Bestuzhev breed, in contrast, a borderline (close to the standard table value of -5.99) value of the $\chi^{2}(6.09)$ criterion was found because of the slight lack of heterozygotes.

In the Hereford and Limousine breeds, the indicators of expected heterozygosity for the TG5 gene differed slightly. The Pearson criterion values were not large, which indicates that the population was in a state of genetic balance.

The results of the analyses of the milk productivity and technological properties of the milk of Blackand-White cows of Bestuzhev and Simmental breeds with different genotypes of the TG5 gene are presented in Table-3. Animals of all three breeds carrying the $T G 5^{T T}$ genotype exhibited the best indicators of milk yield and milk fat. Thus, among the Black-andWhite cows of this genotype, the highest milk yield was $4825.3 \mathrm{~kg}$ and the highest fat content of milk was $3.78 \%$. The difference in milk yield between the $T G 5^{C C}$ and $T G 5^{T T}$ genotypes was $254.6 \mathrm{~kg}$. This difference was significant.

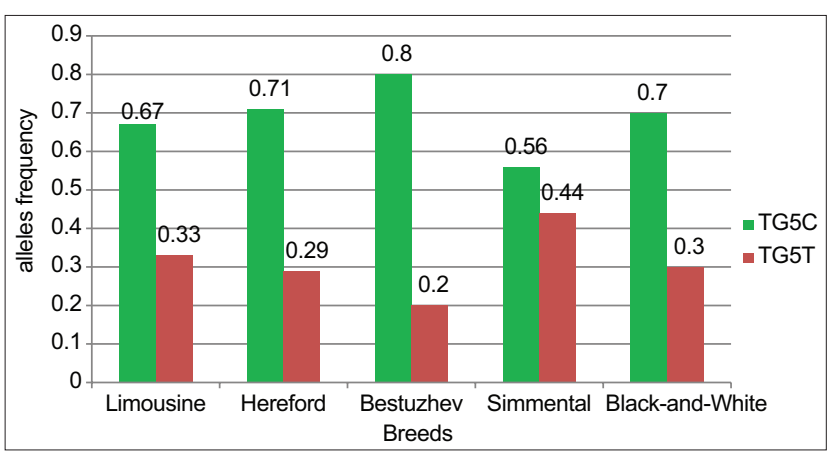

Figure-2: TG5 gene allele's frequency.

Table-2: Actual and expected levels of heterozygousness by the TG5 gene.

\begin{tabular}{lcccc}
\hline Breed & $\mathbf{H}_{\mathbf{o}}$ & $\mathbf{H}_{\mathbf{e}}$ & $\mathbf{F}$ & $\chi^{2}$ \\
\hline Black-and-White & 0.430 & 0.420 & 0.010 & 0.575 \\
Bestuzhev & 0.279 & 0.320 & -0.041 & 6.09 \\
Simmental & 0.627 & 0.493 & 0.134 & 10.66 \\
Hereford & 0.382 & 0.412 & -0.030 & 0.218 \\
Limousine & 0.393 & 0.442 & -0.049 & 0.543 \\
\hline
\end{tabular}

$H_{0}$ is the observed heterozygousness; $H_{e}$ is the expected heterozygousness; $\mathrm{F}$-is the difference of $\mathrm{H}_{\mathrm{o}}-\mathrm{H}_{\mathrm{e}}$; + or - is the excess/deficit of heterozygotes; $\chi^{2}$ is the criterion of matching of the observed and expected distribution of genotypes
No consistent differences in the mass fraction of fat were found in the milk of cows of different genotypes. However, this indicator was higher among animals with the $T G 5^{T T}$ genotype. Black-and-White cows with this genotype had a higher yield of milk fat (13.8 kg higher than that of cows with the $T G 5^{C C}$ genotype). No other consistent differences in milk quality indicators were observed.

Among cows of the Bestuzhev and Simmental breeds, the tendency of the TG5 genotype to affect the milk productivity indicators remains. Thus, cows of both breeds with the $T G 5^{T T}$ genotype have the highest milk yield and milk fat content (in Bestuzhev and Simmental cows, the difference in relation to the $T G 5^{C C}$ genotype was 152.8 and $189.7 \mathrm{~kg}$, respectively, and the mass fraction of fat in milk was $0.38 \%$ and $0.26 \%$, respectively). The fact that the $T G 5^{T T}$ genotype was associated with higher protein content in the milk of Bestuzhev and Simmental breed cows was unexpected. The difference in favor of this genotype compared with the $T G 5^{C C}$ and $T G 5^{C T}$ genotypes was $0.25 \%$ and $0.21 \%$ in the Bestuzhev breed cows, and $0.19 \%$, $0.27 \%$ in the Simmental breed cows, respectively. In terms of milk fat output, cows with the $T G 5^{T T}$ genotype also exhibited a favorable difference.

The data obtained here were in accordance with the results of Kharzinova et al. [22]. According to Kharzinova et al. [22], Black-and-White cows with the $T G 5^{C T}$ genotype have the best milk productivity indicators. Concomitantly, Zinnatova and Zinnatov [17] studied the same breed and found no significant differences between genotypes related to milk productivity indicators.

Table-4 shows the live and postmortem indicators of meat productivity of Hereford and limousine animals with different genotypes of the TG5 gene. The analysis of the indicators presented in Table-4 led us to conclude that calves with different genotypes had the same birth weight. However, at the end of fattening, the bodyweight of bulls with the $T G 5^{C C}$ genotype was increased compared with the bulls with $T G 5^{C T}$ and $T G 5^{T T}$ genotypes. Among Hereford breed bulls with these genotypes, the removable body weight was higher by $1.16 \%$ and $2.04 \%$, and for the Limousine breed, it was higher by $6.65 \%$ and $9.53 \%$, respectively. The animals with the $T G 5^{C C}$ genotype studied here also had higher values of absolute and average daily gains in body weight, pre-slaughter body weight, and carcass yield. These indicators increased in the following order of genotype: $T G 5^{C C}>T G 5^{C T}>T G 5^{T T}$.

Bulls with the $T G 5^{T T}$ genotype for both of the studied breeds had higher indicators of internal raw fat, fat yield, rib-eye fat content, and the ground beef sample compared with bulls with the $T G 5^{C C}$ genotype.

The same indicators were higher in the Hereford breed cattle by $4.98 \% ; 0.25 \% \quad(\mathrm{p}<0.05) ; 0.74 \%$ $(\mathrm{p}<0.05)$; and $0.31 \%(\mathrm{p}<0.05)$, respectively; in the Limousine breed, they were higher by $3.89 \% ; 0.24 \%$ $(\mathrm{p}<0.05) ; 0.95 \% \quad(\mathrm{p}<0.05) ;$ and $0.49 \% \quad(\mathrm{p}<0.05)$, 
Available at www.veterinaryworld.org/Vol.13/October-2020/2.pdf

Table-3: Qualitative indicators of milk from cows with different genotypes for the TG5 gene.

\begin{tabular}{|c|c|c|c|c|c|c|}
\hline \multirow[t]{2}{*}{ Indicator } & \multicolumn{3}{|c|}{ Genotype } & \multicolumn{3}{|c|}{ Difference between genotypes } \\
\hline & TG5 $5^{c C}$ & TG5 ${ }^{c T}$ & TG5 & TG5 $5^{c C} / T_{G} 5^{c T}$ & $T G 5^{C C} / T_{G 5}^{T T}$ & TG5 ${ }^{C T} /$ TGS $^{T T}$ \\
\hline \multicolumn{7}{|c|}{ Black-and-white breed $(n=50)$} \\
\hline Milk yield, kg & $4570.7 \pm 89.0$ & $4756.4 \pm 99.7$ & $4825.3 \pm 95.9$ & -185.7 & $-254.6 *$ & -66.9 \\
\hline Fat, \% & $3.69 \pm 0.05$ & $3.75 \pm 0.02$ & $3.78 \pm 0.04$ & -0.06 & -0.09 & -0.03 \\
\hline Protein, \% & $3.28 \pm 0.07$ & $3.26 \pm 0.01$ & $3.25 \pm 0.08$ & 0.02 & 0.03 & 0.01 \\
\hline Casein, \% & $2.77 \pm 0.10$ & $2.88 \pm 0.05$ & $2.83 \pm 0.09$ & -0.11 & -0.06 & 0.05 \\
\hline Lactose, \% & $4.95 \pm 0.15$ & $4.99 \pm 0.04$ & $4.97 \pm 0.11$ & -0.04 & -0.02 & 0.02 \\
\hline MSNF, \% & $8.91 \pm 0.17$ & $8.97 \pm 0.22$ & $8.95 \pm 0.18$ & -0.06 & -0.04 & 0.02 \\
\hline Milk fat, $\mathrm{kg}$ & $168.6 \pm 5.2$ & $178.3 \pm 4.5$ & $182.4 \pm 4.9$ & -9.7 & $-13.8^{*}$ & -4.1 \\
\hline \multicolumn{7}{|c|}{ Bestuzhev breed $(n=50)$} \\
\hline Milk yield, kg & $3428.4 \pm 88.5$ & $3450.1 \pm 78.9$ & $3581.2 \pm 56.9$ & -21.7 & -152.8 & -131.1 \\
\hline Fat, \% & $3.50 \pm 0.07$ & $3.57 \pm 0.09$ & $3.88 \pm 0.06$ & -0.07 & $-0.38 * *$ & $-0.31 * *$ \\
\hline Protein, \% & $3.22 \pm 0.06$ & $3.26 \pm 0.07$ & $3.47 \pm 0.03$ & -0.04 & $-0.25 * *$ & $-0.21 * *$ \\
\hline Casein, \% & $2.80 \pm 0.17$ & $2.76 \pm 0.11$ & $2.85 \pm 0.10$ & 0.04 & -0.05 & -0.09 \\
\hline Lactose, \% & $4.64 \pm 0.12$ & $4.25 \pm 0.14$ & $4.86 \pm 0.10$ & 0.39 & -0.22 & $-0.61 * *$ \\
\hline MSNF, \% & $8.56 \pm 0.15$ & $8.66 \pm 0.17$ & $9.03 \pm 0.26$ & 0.1 & -0.47 & -0.37 \\
\hline Milk fat, kg & 119. $9 \pm 6.1$ & $123.2 \pm 4.9$ & $138.9 \pm 5.1$ & -3.3 & $-19.0 *$ & $-15.7 *$ \\
\hline \multicolumn{7}{|c|}{ Simmental breed $(n=50)$} \\
\hline Milk yield, kg & $3785.5 \pm 88.5$ & $3829.6 \pm 80.6$ & $3975.2 \pm 56.9$ & -24.1 & $-189.7 *$ & -145.6 \\
\hline Fat, \% & $3.66 \pm 0.08$ & $3.62 \pm 0.09$ & $3.92 \pm 0.09$ & 0.04 & $-0.26 *$ & $-0.3 *$ \\
\hline Protein, \% & $3.37 \pm 0.07$ & $3.29 \pm 0.08$ & $3.56 \pm 0.06$ & 0.08 & $-0.19 *$ & $-0.27 *$ \\
\hline Casein, \% & $2.90 \pm 0.19$ & $2.86 \pm 0.12$ & $2.95 \pm 0.11$ & 0.04 & -0.05 & -0.09 \\
\hline Lactose, \% & $4.52 \pm 0.13$ & $4.50 \pm 0.16$ & $4.55 \pm 0.14$ & 0.02 & 0.03 & 0.05 \\
\hline MSNF, \% & $8.74 \pm 0.17$ & $8.80 \pm 0.23$ & $9.03 \pm 0.17$ & -0.06 & -0.29 & -0.23 \\
\hline Milk fat, kg & $138.5 \pm 7.0$ & $138.6 \pm 6.5$ & $155.8 \pm 4.8$ & -0.1 & $-17.3^{*}$ & $-17.2^{*}$ \\
\hline
\end{tabular}

MSNF=Milk solids non-fat, Significance of differences according to Student's t test $*_{-} p<0,05 ; * *-p<0,01$

Table-4: Meat productivity and quality of meat of bulls of various genotypes by the TG5 gene.

\begin{tabular}{|c|c|c|c|}
\hline \multirow[t]{2}{*}{ Indicator } & \multicolumn{3}{|c|}{ Genotype } \\
\hline & $\operatorname{TG5}^{C C}(\mathrm{n}=\mathbf{2 0})$ & $T_{G 5}{ }^{C T}(\mathrm{n}=20)$ & $T G 5^{T T}(\mathrm{n}=10)$ \\
\hline \multicolumn{4}{|l|}{ Hereford breed $(n=50)$} \\
\hline Bodyweight of newborn calves, $\mathrm{kg}$ & $33.5 \pm 0.28$ & $33.1 \pm 0.35$ & $33.0 \pm 0.42$ \\
\hline Gained bodyweight, kg & $576.25 \pm 5.74$ & $569.6 \pm 5.42$ & $564.7 \pm 6.18$ \\
\hline Absolute body gain, $\mathrm{kg}$ & $542.8 \pm 5.22$ & $536.5 \pm 6.36$ & $531.7 \pm 6.33$ \\
\hline Average daily gain of bodyweight, $\mathrm{g}$ & $892.8 \pm 8.59$ & $882.4 \pm 10.46$ & $874.5 \pm 10.97$ \\
\hline Before slaughter bodyweight, kg & $559.9 \pm 5.80$ & $552.4 \pm 3.06$ & $549.4 \pm 5.20$ \\
\hline Carcass yield, \% & $58.8 \pm 0.53$ & $58.7 \pm 0.42$ & $58.4 \pm 0.60$ \\
\hline Internal raw fat weight, $\mathrm{kg}$ & $19.09 \pm 0.51$ & $19.15 \pm 0.32$ & $20.09 \pm 0.30$ \\
\hline Fat yield, \% & $3.40 \pm 0.09$ & $3.40 \pm 0.05$ & $3.65 \pm 0.07 *$ \\
\hline Slaughter yield, \% & $62.20 \pm 0.24$ & $62.10 \pm 0.27$ & $62.00 \pm 0.18$ \\
\hline The fat content of the rib eye, $\%$ & $5.70 \pm 0.21$ & $6.05 \pm 0.90$ & $6.44 \pm 0.15^{*}$ \\
\hline Fat content in the general sample of ground beef, \% & $14.38 \pm 0.10$ & $14.54 \pm 0.08$ & $14.69 \pm 0.06 *$ \\
\hline \multicolumn{4}{|l|}{ Limousine breed $(n=50)$} \\
\hline Bodyweight of newborn calves, kg & $33.9 \pm 0.30$ & $34.2 \pm 0.27$ & $34.9 \pm 0.23$ \\
\hline Gained bodyweight, kg & $604.1 \pm 3.99$ & $598.1 \pm 2.16$ & $581.4 \pm 6.60$ \\
\hline Absolute bodyweight gain, $\mathrm{kg}$ & $570.2 \pm 4.89$ & $563.9 \pm 3.07$ & $546.5 \pm 4.47$ \\
\hline Average daily bodyweight gain, $g$ & $937.8 \pm 8.05$ & $927.5 \pm 5.05$ & $898.9 \pm 7.34$ \\
\hline Before slaughter bodyweight, kg & $584.0 \pm 6.16$ & $577.4 \pm 0.44$ & $567.0 \pm 4.43$ \\
\hline Carcass yield, \% & $60.0 \pm 0.62$ & $59.9 \pm 0.96$ & $59.9 \pm 0.78$ \\
\hline Internal raw fat weight, $\mathrm{kg}$ & $17.30 \pm 0.18$ & $17.80 \pm 0.17$ & $18.00 \pm 0.33$ \\
\hline Fat yield, \% & $2.95 \pm 0.01$ & $3.06 \pm 0.14$ & $3.19 \pm 0.02 *$ \\
\hline Slaughter yield, \% & $62.90 \pm 0.11$ & $63.10 \pm 0.12$ & $63.10 \pm 0.22$ \\
\hline The fat content of the rib eye, $\%$ & $5.60 \pm 0.28$ & $5.95 \pm 0.28$ & $6.55 \pm 0.16 *$ \\
\hline Fat content in the general sample of ground beef, \% & $13.16 \pm 0.05$ & $13.46 \pm 0.03$ & $13.65 \pm 0.26 *$ \\
\hline
\end{tabular}

Significance of differences according to Student's t test $*$-p $<0,05$

respectively. It should be noted that the Hereford cattle tended to accumulate more fat tissue, which was attributed to the biological characteristics of this breed. Carvalho et al. [10] performed similar studies but did not find a reliable relationship between TG5 gene polymorphism and meat productivity indicators. However, in contrast with our results, their studies proved that the preslaughter weight in animals with the $T G 5^{T T}$ genotype tended to be increased. Our findings confirmed a higher fat yield in animals with the $T G 5^{T T}$ genotype and were consistent with the results of the study of Casas et al. [23]. The increase in fat content in the rib eye is also confirmed by the research of Anton et al. [24], Barendse et al. [7], and Casas et al. [23]. 


\section{Conclusion}

The TG5 gene polymorphism is breed-specific, as proven by the distribution of the frequency of its genotypes and alleles in cattle of the Black-and-White, Simmental, Bestuzhev, Hereford, and Limousine breeds. Dairy cattle showed a clear tendency of an effect of the TG5 genotype on milk productivity indicators. Thus, cows with the $T G 5^{T T}$ genotype had the highest milk yield and fat content in milk. An association between $T G 5$ gene polymorphism and indicators of the intensity of fat metabolism, in particular fat output and fat content in the rib eye and the total sample of ground beef, was found in cattle of both breeds.

When carrying out selection and breeding activities, it is advisable to consider TG5 genotyping as an additional criterion for animal selection, to improve both dairy and meat characteristics.

\section{Authors' Contributions}

ID, TS, FV, RG, DK, AK contributed equally to the experimentation. ID, TS, and DK wrote and edited the article. FV, RG, and AK equally designed and conducted the experiment. ID, DG, and TD studied scientific literature about the topic. All authors read and approved the final manuscript.

\section{Acknowledgments}

The study was a part of the research project of Bashkir state Agrarian University "The study of the genetic resource and the genetic diversity assessment of farm animals of the Republic of Bashkortostan" (state registration No. 115101310075), and "Polymorphism of lipoid metabolism genes in the context of special-type cattle productivity." (state registration No. AAAA - A-18-118060590062-8). We gratefully acknowledge the Chief of the Laboratory of DNA Technologies of Federal State Budgetary Scientific Institution of All-Russia Scientific Research Institute of Breeding, Dr. Sci. in Biology Kalashnikova L.A., a senior scientist researcher of the laboratory, Cand. Sc. Biology Pavlova I. Yu., as well as Candidates of Agricultural Science, senior researchers of the laboratory of molecular genetics of Federal State Budgetary Educational Institution of Higher Education, Bashkir State Agrarian University Ganieva I N. and Kononenko T.V.

\section{Competing Interests}

The authors declare that they have no competing interests.

\section{Publisher's Note}

Veterinary World remains neutral with regard to jurisdictional claims in published institutional affiliation.

\section{References}

1. Dunin, I.M., Tiapugin, S.E., Kalashnikova, L.A., Meshcherov, R.K., Kniazeva, T.A., Khodykov, V.P., Adjibekov, V.K., Kalashnikov, A.E. and Meshcherov, S.R.
(2019) Gene pool of dairy cattle breeds in Russia: State, prospects for conservation and use. Anim. Sci., 5(3): 1-3.

2. Zinovieva, N.A., Seregin, A.A., Diev, A.V., Voronetska, O.I., Patrikeeva, L.V., Abdulmanov, A.S. and Brem, G. (2019) Animal genetic resources: Development of research on the allelo-fund of Russian cattle breeds. Agric. Boil., 54(4): 631-641.

3. Mészáros, G., Sölkner, J., Fornara, M., Brem, G., Sermyagin, A., Zinovieva, N., Reyer, H. and Wimmers, K. (2019) Elevated haplotypes frequencies reveal similarities for selection signatures in the Western and Russian Simmental population. J. Cent. Eur. Agric., 20(1): 1-11.

4. Shin, S.C. and Chung, E.R. (2017) Association of SNP marker in the thyroglobulin gene with carcass and meat quality traits in Korean Cattle. Asian Aust. J. Anim. Sci., 20(2): 172-177.

5. Kadrov, V.I. (2005) Thyroid hormones: Biosynthesis and mechanism of action. Russ. Chem. J., 49(1): 75-83.

6. Ardicli, S., Samli, H., Dincel, D., Ekiz, B., Yalcintan, H., Vatansever, B. and Balci, F. (2018) Relationship of the bovine IGF1, TG, DGAT1 and MYF5 genes to meat colour, tenderness and cooking loss. J. Hell. Vet. Med. Soc., 69(3): 1077-1087.

7. Barendse, W., Bunch, R., Thomas, M., Armitage, S., Baud, S., Donaldson N. (2004) The TG5 thyroglobulin gene test for a marbling quantitative trait loci evaluated in feedlot cattle. Aust. J. Exp. Agric., 44 (7):669 -674.

8. Chernitskiy, A., Shabunin, S., Kuchmenko, T. and Safonov, V. (2019) On-farm diagnosis of latent respiratory failure in calves. Turk. J. Vet. Anim. Sci., 43(6): 707-715.

9. Gan, Q.F., Zhang, L.P., Li, J.Y., Hou, G.Y., Li, H.D., Gao, X., Ren, H.Y., Chen, J.B. and Xu, S.Z. (2008) Association analysis of thyroglobulin gene variants with carcass and meat quality traits in beef cattle. J. Appl. Genet., 49(3): 251-255.

10. Carvalho, T.D., Siqueira, F., Júniok, R.A.A., Medeiros, S.R., Feijó, G.L.D., Junior, M.D.S., Blecha, I.V.Z. and Soares, C.O. (2012) Association of polymorphisms in the leptin and thyroglobulin genes with meat quality and carcass traits in beef cattle. Rev. Bras. Zootec., 41(10): 2162-2168.

11. Anton, I., Kovács, K., Holló, G., Farkas, V., Szabó, F., Egerszegi, I., Rátky, J., Zsolnai, A. and Brüssow, K.P. (2012) Effect of DGAT1, leptin, and TG gene polymorphisms on some milk production traits in different dairy cattle breeds in Hungary. Arch. Anim. Breed., 55(4): 307-314.

12. Dzhulamanov, K., Gerasimov, N., Dubovskova, M. and Baktygalieva, A. (2019) Polymorphisms of CAPN1, CAST, GDF5, TG5 and GH genes in Russian Hereford cattle. Bulg. J. Agric. Sci., 25(2): 375-379.

13. Fortes, M.R., Curi, R.A., Chardulo, L.A., Silveira, A.C., Assumpção, M.E., Visintin, J.A. and Oliveira, H.N. (2009) Bovine gene polymorphisms related to fat deposition and meat tenderness. Genet. Mol. Biol., 32(1): 75-82.

14. Safonov, V. (2020). Assessment of Heavy Metals in Milk Produced by Black-and-White Holstein Cows from Moscow. Curr. Res. Nutr. Food Sci., 8(2): 410-415.

15. Selionova, M., Dubovskova, M., Chizhova, L., Mikhailenko, A., Surzhikova, E. and Plakhtyukova, V. (2019) Fatty acid composition of blood lipids of young beef cattle of different genotypes of CAPN1, GH, TG5, LEP genes. In: IOP Conference Series: Earth and Environmental Science. Vol. 341.

16. Tiul'kin, S.V., Akhmetov, T.M., Valiullina, E.F. and Vafin, R.R. (2013) Polymorphism of somatotropin, prolactin, leptin, and thyroglobulin genes in bulls. Russ. J. Genet. Appl. Res., 3(3): 222-224.

17. Zinnatova, F.F. and Zinnatov, F.F. (2014) The role of lipid metabolism genes (DGAT1, TG5) in improving the economic and useful characteristics of cattle. Sci. Notes Kazan State Acad. Vet. Med., 3(1): 164-168.

18. Kalashnikova, L.A., Habibrahmanova, J.A., Pavlova, I.Y., Ganchenkova, T.B., Dunin, I.M. and Pridanova, I.E. (2015) Recommendations for Genomic Assessment of Cattle. 
All-Russian Research Institute of Breeding, Forest Glades. p42.

19. Soloshenko, V.A., Goncharenko, G.M., Inerbaev, B.O., Khramtsova, I.A., Goriacheva, T.S. and Grishina, N.B. (2011) Influence of thyroglobulin and somatotropin gene polymorphism on the growth rate of cattle. Probl. Biol. Prod. Anim., 1(1): 55-58.

20. Sharipov, A.A., Shakirov, S.K., Iulmetieva, Y.R. and Gafurova, L.I. (2014) Molecular and genetic aspects of the selection of meat cattle by marbling. Bull. Meat Cattle Breed., 2(85): 59-64.

21. Dobrianska, M.L. (2014) Genetic structure of cattle meat breeds by different DNA marker types. Breed. Genet. Anim., 48:183-188.

22. Kharzinova, V.R., Zinovieva, N.A. and Gladyr, E.A. (2011)
Polymorphism of DNA markers DGAT1, TG5, and GH in connection with the linear affiliation and level of milk productivity of black-and-white cows. Probl. Biol. Prod. Anim., 1(2): 73-77.

23. Casas, E., White, S.N., Riley, D.G., Smith, T.P.L., Brenneman, R.A., Olson, T.A., Johnson, D.D., Coleman, S.W., Bennett, G.L. and Chase, C.C. (2005) Assessment of single nucleotide polymorphisms in genes residing on chromosomes 14 and 29 for association with carcass composition traits in Bos indicus cattle. J. Anim. Sci., 83(1): 13-19.

24. Anton, I., Kovács, K., Holló, G., Farkas, V., Lehel, L., Hajda, Z. and Zsolnai, A. (2011) Effect of leptin, DGAT1 and TG gene polymorphisms on the intramuscular fat of Angus cattle in Hungary. Livest. Sci., 135(2-3): 300-303.

$* * * * * * * *$ 